\title{
Globalization of leptospirosis through travel and migration
}

\author{
Medhani Bandara', Mahesha Ananda' ${ }^{1}$ Kolitha Wickramage² ${ }^{2}$ Elisabeth Berger $^{3}$ and Suneth Agampodi ${ }^{1,{ }^{*}}$
}

\begin{abstract}
Leptospirosis remains the most widespread zoonotic disease in the world, commonly found in tropical or temperate climates. While previous studies have offered insight into intra-national and intra-regional transmission, few have analyzed transmission across international borders. Our review aimed at examining the impact of human travel and migration on the re-emergence of Leptospirosis. Results suggest that alongside regional environmental and occupational exposure, international travel now constitute a major independent risk factor for disease acquisition. Contribution of travel associated leptospirosis to total caseload is as high as $41.7 \%$ in some countries. In countries where longitudinal data is available, a clear increase of proportion of travel-associated leptospirosis over the time is noted. Reporting patterns is clearly showing a gross underestimation of this disease due to lack of diagnostic facilities. The rise in global travel and eco-tourism has led to dramatic changes in the epidemiology of Leptospirosis. We explore the obstacles to prevention, screening and diagnosis of Leptopirosis in health systems of endemic countries and of the returning migrant or traveler. We highlight the need for developing guidelines and preventive strategies of Leptospirosis related to travel and migration, including enhancing awareness of the disease among health professionals in high-income countries.
\end{abstract}

Keywords: Leptospirosis, Travel, Migration

\section{Introduction}

Leptospirosis has traditionally been described in the medical literature as a treatable zoonotic disease endemic to low-income countries in temperate and tropical regions [1]. As a clinical entity it is strongly associated with regional occupational and environmental exposures [2]. WHO Leptospirosis Burden Epidemiology Reference Group (LERG) estimates [3], 873,000 annual cases and 48,000 deaths due to leptospirosis [4]. The countries with the highest reported incidence are located in the AsiaPacific region (Seychelles, India, Sri Lanka and Thailand) with incidence rates over 10 per 1000,000 people s well as in Latin America and the Caribbean (Trinidad and Tobago, Barbados, Jamaica, El Salvador, Uruguay, Cuba, Nicaragua and Costa Rica) [5].

In recent years however, recreational exposure to water has emerged as a strong risk-factor for disease

\footnotetext{
* Correspondence: sunethagampodi@yahoo.com

'Department of Community Medicine, Faculty of Medicine and Allied

Sciences, Rajarata University of Sri Lanka, Saliyapura, Sri Lanka

${ }^{4}$ Tropical Disease Research Unit, Faculty of Medicine and Allied Sciences, Rajarata University of Sri Lanka, Saliyapura, Sri Lanka

Full list of author information is available at the end of the article
}

transmission [6]. Over the past twenty years, leptospirosis cases diagnosed among international travelers have become increasingly common [7] and the disease is now emerging as a major public health concern worldwide [5]. Both neglected and under-reported, there is scant epidemiological data on leptospirosis therefore masking the true scope of disease prevalence and making reliable morbidity and mortality statistics difficult to ascertain [3]. Chronic underreporting of leptospirosis is due in large part to clinical misdiagnosis [8]. Patients present with clinical signs difficult to distinguish from other endemic illnesses including dengue fever, malaria, HIV, rickettsial disease and yellow fever. Further, regional and district level health centers often lack appropriate diagnostic laboratories to perform the serological testing required to establish a diagnosis [9].

To date, studies investigating leptospirosis have described high disease prevalence among economically marginalized populations in endemic regions. Urban slums [10-15] lacking access to adequate sewage disposal and water treatment infrastructure as well as rural farming communities working in rice [16-20] or sugar cane fields [21-23] have been 
highlighted as communities facing the highest risk. These populations are particularly vulnerable to seasonal monsoons and flooding which can heighten the risk of transmission and lead to outbreaks and possible epidemics. Additionally, high-risk occupational groups for the disease include fishermen [24], sewer workers [25], dairy industry workers [26], veterinarians [27], miners [28] and military personnel [29-32]. In countries where disease is regionally endemic, internal migration patterns and exposures are crucial risk factors for the spread of the disease.

The rise in global travel and eco-tourism [33] has led to dramatic changes in the epidemiology of leptospirosis. Despite decreasing prevalence of leptospirosis in endemic regions, previously non-endemic countries are now reporting increasing numbers of cases due to recreational exposure [34]. International travelers engaged in adventure sports are directly exposed to numerous infectious agents in the environment and now comprise a growing proportion of cases worldwide. Similarly, in recent years outdoor athletic events have been linked with several outbreaks among foreign travelers.

To date, the global impact of international travel and migration as a major determinant of leptospirosis transmission has yet to be thoroughly analyzed in the medical literature. In this paper we aim to evaluate the impact of human migration and recreational travel on the reemergence of leptospirosis.

\section{Methods}

\section{Search strategy}

We conducted a comprehensive review of existing leptospirosis literature via online databases. Our principle aim was to identify all studies published in peer-reviewed journals and indexed in PubMed that explored the association between human migration and leptospirosis published through March 2013. Although non-English studies were excluded, we extracted data from studies that had English abstracts. To identify relevant articles not found in PubMed, we supplemented the search strategy by first searching the indices of several journals manually: Travel Medicine and Infectious Disease, Journal of Travel Medicine, International Medical Travel Journal, International Journal of Travel Medicine and Global Health, and second by reviewing reference lists of primary studies.

\section{Inclusion criteria and definitions}

Studies that reported confirmed and probable cases of leptospirosis were deemed eligible for inclusion. Reviewers screened citations by reviewing titles and abstracts to identify potentially relevant studies. Disagreements between the reviewers were resolved by consensus. The database was then screened a second time using more focused inclusion criteria to isolate only primary articles. Subsequently the full text of each citation was obtained and reviewed. In cases where full articles could not be obtained, the article abstract was used. We adopted the case-definition of leptospirosis based on the guidelines from the LERG [35] to include studies in the review. No restrictions were made with regard to the outcome variables as this was a review of observational studies.

\section{Data extraction}

A data collection form was prepared and pilot tested prior to data extraction activities begun. In order to minimize biases in data extraction, the methods of selected studies were reviewed in detail by two independent reviewers under the supervision of the principle investigator. Subgroup analyses were done to minimize heterogeneity across studies. Data were pooled only when studies were reasonably consistent in their methods. Variables were examined in detail, including: number of cases, country of residence, exposure country/region, proportion of travel related cases, type and nature of study (population based vs. hospital based cohort), type of exposure, time period and year.

\section{Results}

Of the 10,289 articles we identified on leptospirosis, only 141 met the key-word criteria related to travel/migration. We identified a total of 149 potentially relevant citations from both the PubMed and cumulative literature search once duplicate references were removed. These were further reduced to 60 after undertaking a title and abstract review. Following an in-depth review of the full-texts of these papers 48 were included for final analysis (Figure 1).

Of the 54 publications, 33 reported individual travel reported leptospirosis cases or case reports, nine reported cases by country and/or regional caseload and six reported cases in the context of travel related fever. After the full text review 12 articles were excluded from final qualitative analysis. We excluded a case acquired due to an imported animal, five reports without primary data and six reviews from the final qualitative data analysis. All studies we encountered clearly identified the geographical region where disease was acquired.

Data extraction was completed for 3 distinct subgroups:

1. Papers citing travel as a significant contributory factor to overall country level leptospirosis case loads (9 studies)

2. Those that highlighted the contribution of leptospirosis to larger trends in travel associated fever (5 studies); and

3. Case reports and case series illustrating travelassociated leptospirosis (33 studies)

The nine studies reporting cases of leptospirosis among travellers or migrants as a proportion of the 


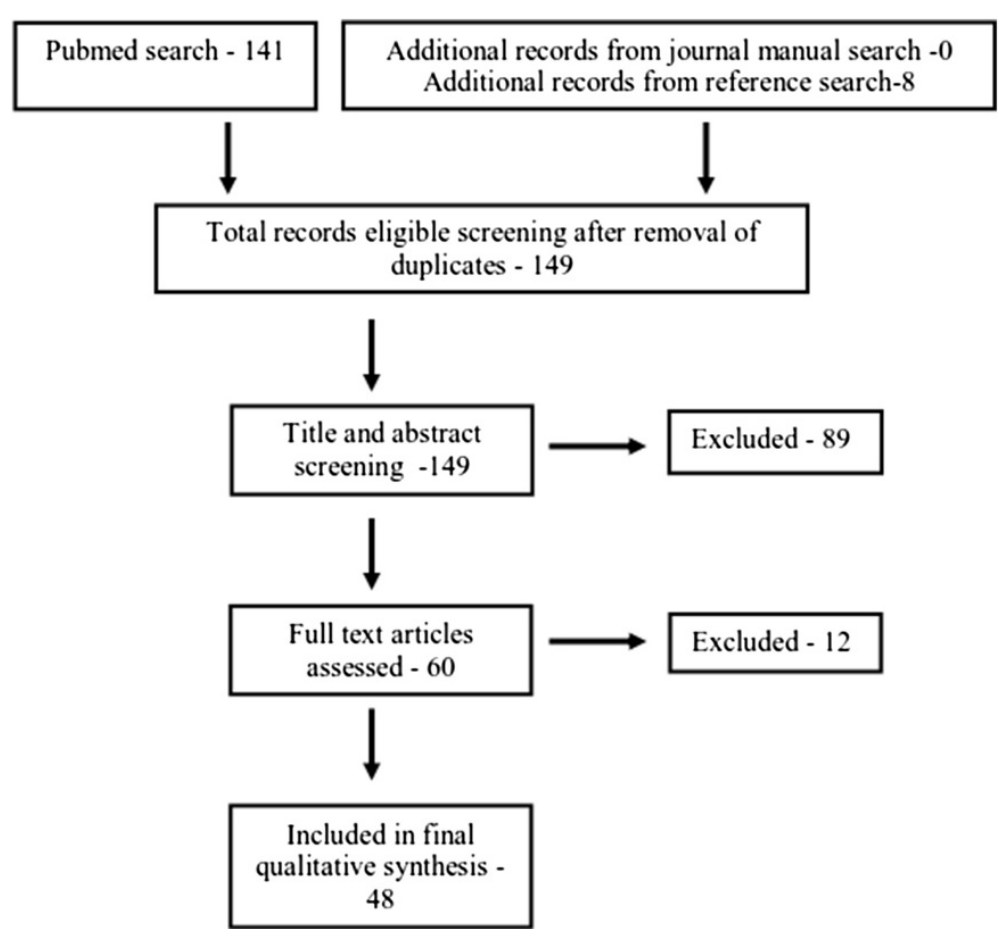

Figure 1 Selection of studies for review.

general population contained data of 6 countries: The Netherlands [36,37], Israel [38], Germany [39,40], Austria [39], Japan [41,42], Thailand [43] and the USA [44] (Table 1), all of which are high-income nations with the exception of Thailand. In the USA, country level data was not available, but complete data set for Hawaii was available only up through 2008.

Among reports of systematically collected country level data, Israel reported the highest incidence of travel associated leptospirosis (41.7\%). In Germany, before 2003 this contribution was only $15.7 \%$. However, a later study showed that the travel related cases increased up to $40.7 \%$ in 2008 . Netherland has the largest reported database describing travel associated leptospirosis which included 318 cases out of 2553 cases related to international travel. In Germany and Netherlands, intra-country travel comprised over $40 \%$ of the disease burden. One study conducted in Germany using aggregate data from 19622002 found that 13 out of 39 travel related leptospirosis cases were acquired from European countries where leptospirosis is rare, with the majority of these cases occurring between 1960 and 1980. The study results suggest that in the last two decades, this trend has shifted, with Latin America and Caribbean Islands serving as the main geographical location for disease transmission and infection among German nationals. Data from Japan reports that around $7 \%$ are none residents thus travel related. Data from Hawaii shows that $5.7 \%$ of leptospirosis cases reported in Hawaii were from mainland USA and $23 \%$ from smaller islands. Other than Hawaii islands where Leptospirosis is endemic and disease transmission was within the state, the major contribution to travel related leptospirosis was from southeast Asia/Asia.

Contribution of leptospirosis to travel associated fever was reported among more than 7000 febrile cases in six studies (Table 2). All studies were from developed countries. Leptospirosis was responsible for $0.21 \%$ to $2.65 \%$ of all travel associated fever cases. Among Western travelers, which included travelers from North America, Europe, Israel, Japan, Australia and New Zealand, leptospirosis contributed to $2.65 \%$ of all travel related febrile illnesses [45]. Individual reports from Sweden [46], Australia [47] and Finland [48] and combined reports by Flores-Figueroa et al. [49] and Field et al. [50] showed less than 1\% contribution. South East Asia was reported as the main exposure area.

Of the 27 case reports and 6 case series, 3 reported on leptospirosis due local travel within the country. Two of these studies examined transmission from the continental US to Hawaii [51,52] and from the Jordan River Valley in Israel to the northern part of the country [32]. All other case reports were focused on infection secondary to travel outside of the patients' country of residence (Table 3) which included 11 countries; Germany (7) [53-59], Netherlands (5) [60-64], France (5) [65-69] Australia (3) [70-72], USA (4) [73-77], Israel (1), Canada (1) [78], Norway (1) [79], Italy (1) [80], Japan (1) [81], and Sweden (1) [82]. Leading exposure countries were 
Table 1 Country level data and proportion of travel related leptospirosis

\begin{tabular}{|c|c|c|c|c|c|c|c|}
\hline Reference & Country & $\begin{array}{l}\text { Period of } \\
\text { study }\end{array}$ & $\begin{array}{l}\text { Total } \\
\text { cases }\end{array}$ & $\begin{array}{l}\text { Travel } \\
\text { associated } \\
\text { cases }\end{array}$ & Country of exposure & Type of exposure & $\begin{array}{l}\text { Positive test } \\
\text { that was diagnostic } \\
\text { of leptospirosis }\end{array}$ \\
\hline \multirow{8}{*}{$\begin{array}{l}\text { Goris, Kimberly } \\
\text { et al., [36] }\end{array}$} & \multirow[t]{8}{*}{ Netherlands } & \multirow[t]{8}{*}{$1925-2008$} & \multirow[t]{8}{*}{2553} & \multirow[t]{8}{*}{$318(12.5 \%)$} & Europe - 132 & \multirow[t]{2}{*}{ Recreational- 257, } & \multirow[t]{8}{*}{ Culture/MAT } \\
\hline & & & & & Asia - 134 & & \\
\hline & & & & & South America - 25 & \multirow[t]{2}{*}{ Job-related 21, } & \\
\hline & & & & & Central and North & & \\
\hline & & & & & America - 13 & \multirow[t]{4}{*}{ Accidental 22, } & \\
\hline & & & & & Sub-Saharan Africa - 7 & & \\
\hline & & & & & Middle East - 2 & & \\
\hline & & & & & Australia - 1 & & \\
\hline \multirow[t]{4}{*}{ Leshem et al., [38] } & \multirow[t]{4}{*}{ Israel } & \multirow[t]{4}{*}{$2002-2008$} & \multirow[t]{4}{*}{48} & \multirow[t]{4}{*}{$20(41.7 \%)$} & Southeast Asia - 15, & \multirow{4}{*}{$\begin{array}{l}\text { Participation in water } \\
\text { related activities }\end{array}$} & \multirow[t]{4}{*}{ Not mentioned } \\
\hline & & & & & Africa - 2, & & \\
\hline & & & & & Oceania - 2, Central & & \\
\hline & & & & & America - 1 & & \\
\hline \multirow{3}{*}{$\begin{array}{l}\text { Hoffmeister et al., } \\
\text { [39] }\end{array}$} & \multirow{3}{*}{$\begin{array}{l}\text { Germany and } \\
\text { Austria }\end{array}$} & \multirow[t]{3}{*}{ 1998-2008 } & \multirow[t]{3}{*}{59} & \multirow[t]{3}{*}{$24(40.7 \%)$} & Caribbean - 10, & \multirow[t]{3}{*}{ Recreational } & \multirow[t]{3}{*}{ ELISA, MAT, PCR } \\
\hline & & & & & $\begin{array}{l}\text { Asia - 9, Eastern Europe - 3, } \\
\text { Central America - 1, }\end{array}$ & & \\
\hline & & & & & South America - 1 & & \\
\hline Taniguchi et al., [42] & Japan & 1999-2008 & 95 & $7(7.4 \%)$ & Not mentioned & Not mentioned & Not mentioned \\
\hline \multirow[t]{7}{*}{ Jansen et al., [40] } & \multirow[t]{7}{*}{ Germany } & \multirow[t]{7}{*}{$1997-2003$} & 248 & $39(15.7 \%)$ & France - 4, & Not mentioned & Not mentioned \\
\hline & & & & & Greece - 2, & & \\
\hline & & & & & Poland - 2, & & \\
\hline & & & & & Hungary - 2 & & \\
\hline & & & & & Norway-1, & & \\
\hline & & & & & Croatia-1, & & \\
\hline & & & & & Bulgaria-1 & & \\
\hline Narita et al., [41] & Japan & 1999 & 14 & $9(62.3 \%)$ & & $\begin{array}{l}\text { Exposure to } \\
\text { contaminated } \\
\text { soil or water }\end{array}$ & Not mentioned \\
\hline $\begin{array}{l}\text { Ariyapruchya et al., } \\
\text { [43] }\end{array}$ & Thailand & $1994-2000$ & 59 & 10(16.9\%) & $\begin{array}{l}\text { Northeastern part of } \\
\text { Thailand }\end{array}$ & & \\
\hline Katz et al., [44] & USA & $1974-1998$ & 752 & $43(5.7 \%)$ & 43 - outside the state & & \\
\hline & & & & & $\begin{array}{l}27 \text { - Federated States of } \\
\text { Micronesia, }\end{array}$ & & \\
\hline & & & & & 6 -American Samoa, & & \\
\hline & & & & & 4 - Guam, & & \\
\hline & & & & & from Costa Rica-2 & & \\
\hline & & & & & Thailand-1, & & \\
\hline & & & & & Philippines-1 & & \\
\hline & & & & & Mexico-1 & & \\
\hline & & & & & Utah-1 & & \\
\hline Crevel et al., [37] & Netherlands & $1987-1991$ & 237 & $32(13.5 \%)$ & Thailand -24 & $\begin{array}{l}\text { Contact with } \\
\text { freshwater, }\end{array}$ & MAT,ELISA \\
\hline & & & & & $\begin{array}{l}\text { Other Southeast Asian } \\
\text { countries-4, }\end{array}$ & $\begin{array}{l}\text { 21- water-rafting } \\
\text { in Thailand }\end{array}$ & \\
\hline & & & & & Ivory Coast-1, & & \\
\hline & & & & & Surinam-3 & & \\
\hline
\end{tabular}


Table 2 Leptospirosis cases detected out of travelers presenting with fever

\begin{tabular}{|c|c|c|c|c|c|c|}
\hline Reference & Country & Period of study & Total cases & Total fever cases & Country of exposure & Type of travel \\
\hline \multirow[t]{2}{*}{ Jensenius et al., [45] } & $\begin{array}{l}\text { North America, } \\
\text { Europe, Israel, } \\
\text { Japan, Australia, } \\
\text { New Zealand }\end{array}$ & $1996-2011$ & $88(2.65 \%)$ & 3326 & $\begin{array}{l}\text { Caribbean - 7, } \\
\text { Central America - 15, } \\
\text { North Africa - 3, Oceania - 2, } \\
\text { South America - 4, } \\
\text { South Central Asia - 3, } \\
\text { Southeast Asia - 49 } \\
\text { (Thailand - 19, Laos - 11), } \\
\text { Sub-Saharan Africa - } 5\end{array}$ & $\begin{array}{l}\text { Tourists-82\% Others; } \\
\text { on business and } \\
\text { visiting friends } \\
\text { and relatives }\end{array}$ \\
\hline & Canada - 1 & & & & & \\
\hline \multirow[t]{2}{*}{$\begin{array}{l}\text { Flores-Figueroa } \\
\text { et al., [49] }\end{array}$} & USA - 4 & $1996-2010$ & $6(0.75 \%)$ & 804 & $\begin{array}{l}\text { Costa Rica, Mexico, } \\
\text { Panama }\end{array}$ & $\begin{array}{l}\text { Tourist, missionary } \\
\text { and business }\end{array}$ \\
\hline & France - 1 & & & & & \\
\hline Siikamaki et al., [48] & Finland (Helsinki) & $2005-2009$ & $1(0.21 \%)$ & & Asia & Unknown \\
\hline Field et al., [50] & Europe & 2008 & $7(0.50 \%)$ & 1378 & $\begin{array}{l}\text { Cambodia-2, Cameroon-1, } \\
\text { Central African Republic-1, } \\
\text { Costa Rica-1, Indonesia-1, } \\
\text { Reunion-1 }\end{array}$ & Unknown \\
\hline Askling et al., [46] & Sweden & $2005-2008$ & $7(0.50 \%)$ & 1432 & $\begin{array}{l}\text { Tropical countries - Africa, } \\
\text { Asia, America }\end{array}$ & Unknown \\
\hline Goldsmid et al., [47] & Australia (Tasmania) & & 1 & NR & India & Studies (river) \\
\hline
\end{tabular}

from South East Asian region, including Thailand, Malaysia and Philippines which accounted for more than $1 / 3$ rd of cases. All case reports and case series were from high income countries.

\section{Discussion}

The results from this review suggest a dynamic shift in the epidemiology of leptospirosis transmission due to increased human travel and migration on a global scale. While previous studies have offered insight into intra-national and intra-regional transmission, few have analyzed transmission across international borders. The results presented here suggest that secondary transmission of leptospirosis via human travel and migration across national borders is re-shaping the landscape of disease incidence and prevalence worldwide. Alongside regional environmental and occupational exposure, international travel now constitutes a major independent risk factor for disease acquisition.

Despite increases in travel-associated disease, the overall contribution of diagnosed leptospirosis to cases of febrile illness in returning travelers is still quite low (2.4\%) [45]. This discrepancy is likely due to the lack of clinical suspicion among home-country clinicians as leptospirosis is rarely included in the differential diagnosis outside of endemic regions. Additional obstacles to diagnosis include the lack of home-country diagnostic facilities and general diagnostic inaccuracy due to serovar diversity between geographic regions. Countries having the highest number of cases detected in travelers returning from endemic regions (United States, Netherlands, Japan, France, Germany and Australia) are also equipped with highly developed reference laboratories, diagnostic capacity and research facilities. Such capacities may be limited in developing countries where tourist travel to endemic countries is equally common, ultimately leading to poor case detection and reporting bias.

In an era of globalization with increased global travel and migration, diseases that were thought to be isolated to tropical regions or affecting marginalized communities can no longer be considered as tightly contained' static entities [5]. It is imperative to view new international trends in transmission as a direct outgrowth of globalization. Such diseases are not emerging threats, but rather have been threats all along. Confined to mostly impoverished fishing and rice farming communities, Leptospirosis has for many decades gone largely undetected and neglected. The disease has also been a leading cause of morbidity and mortality in such communities for generations. Although Leptospirosis remains the most widespread zoonotic disease in the world, the greatest burden of the disease still remains with such marginalized communities. They face daily occupational exposure risks in order to earn their livelihoods. The new trends in global transmission stands as an important reminder that it is essential to design and implement a rigorous disease detection, prevention and treatment plan starting first at the community level.

Due to the complexity of the disease transmission, primary prevention of leptospirosis is difficult. In low and middle income tropical countries, the ecological system provides a conducive environment for leptospirosis transmission. Identification of local 'hot spots' of leptospirosis may help facilitate preventive activities. Public health authorities in endemic areas should 
Table 3 Case reports and case series on travel related leptospirosis

\begin{tabular}{|c|c|c|c|c|}
\hline Reference & Country & Country of exposure & Region/City & Disease confirmation \\
\hline Walter et al., [54], & Germany & Canada & & \\
\hline Grobusch et al., [53] & Germany & Dominican Republic & $\begin{array}{l}\text { Playa Dorada, Santiago/Los Ciruelitos, } \\
\text { Santa Domingo, Juan Dolio, Mao }\end{array}$ & ELISA \\
\hline Teichmann et al., [59] & Germany & Philippines & & MAT \\
\hline Green and Busuttil, [58] & Germany & Sardinia & & \\
\hline Bernasconi et al., [57] & Germany & Switzerland & Southern & \\
\hline Steffens et al., [56] & Germany & Thailand & & Serology, PCR \\
\hline Seilmaier and Guggemos [55] & Germany & Thailand and Laos & & Serology \\
\hline Gelman et al., [73] & USA & Ecuador, Costa Rica & & Culture, Dark field microscopy \\
\hline Duplessis et al., [51] & USA & Hawaii & Maunuwili falls & \\
\hline Pashkow et al., [75] & USA & Honduras & & \\
\hline Haake et al., [76] & USA & Malaysia & Sabah & Dip-S-Ticks, PanBio ELISA, Culture \\
\hline Mortimer [74] & USA & Malaysia & Sarawak & \\
\hline Coursin et al., [52] & USA & USA & Hawaii & MAT \\
\hline Monsuez et al., [67] & France & Africa & Cote d'Ivoire (Ivory Coast) & ELISA \\
\hline Perret et al., [68] & France & Gabon & & $\lg M$ \\
\hline Jaureguiberry et al., [66] & France & Ivory Coast - 1, China - 1 & & ELISA, MAT \\
\hline Simon et al., [69] & France & Mauritius Island & & ELISA, MAT, PCR \\
\hline Arzouni et al., [65] & France & Portugal and Spain & & $\begin{array}{l}\text { Dark field microscopy, PCR, } \\
\text { Western blot, Culture }\end{array}$ \\
\hline Maldonado et al., [64] & Netherlands & China & & MAT \\
\hline Arcilla et al., [60] & Netherlands & Dominican Republic & Altos de Chavón & MAT, ELISA, PCR \\
\hline Wagenaar et al., [63] & Netherlands & Malaysia & Langkawi island & ELISA, MAT \\
\hline Helmerhorst et al., [61] & Netherlands & Thailand & Bangkok and the North of Thailand & MAT \\
\hline Kager et al., [62] & Netherlands & Thailand & & Serology Culture \\
\hline Heron et al., [70] & Australia & Africa, Ghana & Ghana & \\
\hline Gill et al., [71] & Australia & Fiji & & ELISA (lgM) \\
\hline Korman et al., [72] & Australia & Indonesia & Kalimantan & MAT, Culture, Dark field microscopy \\
\hline Hadad et al., [32] & Israel & Israel & Jordan river (Nothern Israel) & MAT \\
\hline Paz et al., [77] & Israel & Thailand, Cambodia & Kochang island, Thailand & MAT \\
\hline Leung et al., [78] & Canada & Malaysia & Northeastern Malaysia & ELISA, MAT \\
\hline Lagi et al., [80] & Australia & Italy & Venice & PCR, MAT \\
\hline Sakamoto et al., [81] & Japan & Indonesia & Bali island & Dark field microscopy, MAT \\
\hline Myrstad et al., [79] & Norway & France & Southern France & $\lg M, \lg G$ \\
\hline Guron et al., [82] & Sweden & Thailand & & Serology \\
\hline
\end{tabular}

coordinate with regional level authorities to compile and monitor epidemiological trends with the goal of actively identifying geographical areas which would benefit from increased service provision and education. If these hot spots correspond with mass gatherings or tourist attractions, then application of targeted primary and secondary preventive measures may become more feasible. As an example, recent reports of internal travel associated leptospirosis occured in Sri Lanka, in a place where white color workers were engaged in water sport [83]. Interventions were needed to target those involved in organizing recreational travel packages for white-water rafting in such settings. Strategies may also include participant education and chemoprophylaxis to prevent leptospirosis in those registering for such activities. Recent increase in leptospirosis among people engaged in water sports also pose the question of whether chemoprophylaxis should be taken as a routine practice. Since the evidence to support the use of chemoprophylaxis is still poor, more studies are needed to inform decision making [84].

The results of this review highlight the urgent need for developing travel guidelines and preventive strategies of 
leptospirosis related to travel. Awareness of leptospirosis among health professionals practicing in high-income countries where the disease seems exotic is essential for proper diagnosis and treatment. Further, stake holders such as tour companies, adventure sport organizers should also receive adequate knowledge on the increasing risk of leptospirosis.

Further research is needed to investigate the impact of occupational migration and forced displacement on leptospirosis prevalence and disease distribution. Given that migrant workers and refugees are often the most marginalized and underserved communities, detection, treatment and prevention of leptospirosis among this high-risk cohort has been largely ignored to date. Lastly additional studies are needed to assess the efficacy of long-term chemoprophylaxis with doxycycline and to identify other alternative less toxic agents for long-term use in high-risk groups.

We undertook our literature review using PubMed as the main electronic database with hand-searches of selected bibliographies to identify additional relevant literatures. This may not have captured an exhaustive list of literature. We did not analyze the disease transmission risk associated with the total length of time traveling, exposure history, route of transmission, visits to multiple regions in succession, occupation and clinical presentation stand as possible confounding variables which should be done in future studies.

\section{Competing interests}

All authors declare (1) no support from any organization for the submitted work; (2) no financial relationships with any organizations that might have an interest in the submitted work in the previous three years; and (3) no other relationships or activities that could appear to have influenced the submitted work.

\section{Authors' contribution}

$M B$ and MA carried out the literature search, data extraction and table preparation. $\mathrm{MB}$ and $\mathrm{EB}$ analyzed and interpreted data and prepared the draft manuscript. EB completed the manuscript writing. KW and SA conceived the study, design the methodology, revised the final manuscript and coordinated the review process. All authors read and approved the final manuscript.

\section{Author details}

${ }^{1}$ Department of Community Medicine, Faculty of Medicine and Allied Sciences, Rajarata University of Sri Lanka, Saliyapura, Sri Lanka. ${ }^{2}$ International Organization for Migration, Colombo, Sri Lanka. ${ }^{3}$ Medical School for International Health (MSIH), Faculty of Health Sciences, Ben-Gurion University of the Negev, Beersheba, Israel. ${ }^{4}$ Tropical Disease Research Unit, Faculty of Medicine and Allied Sciences, Rajarata University of Sri Lanka, Saliyapura, Sri Lanka.

Received: 25 May 2014 Accepted: 23 July 2014

Published: 12 August 2014

\section{References}

1. Bharti AR, Nally JE, Ricaldi JN, Matthias MA, Diaz MM, Lovett MA, Levett PN, Gilman RH, Willig MR, Gotuzzo E, Vinetz JM: Leptospirosis: a zoonotic disease of global importance. Lancet Infect Dis 2003, 3:757-771.

2. Murhekar MV, Sugunan AP, Vijayachari P, Sharma S, Sehgal SC: Risk factors in the transmission of leptospiral infection. Indian J Med Res 1998, $107: 218-223$
3. Abela-Ridder B, Sikkema R, Hartskeerl RA: Estimating the burden of human leptospirosis. Int J Antimicrob Agents 2010, 36(Suppl 1):S5-7.

4. Abela-Ridder B, Bertherat E, Durski K: Global burden of Human Leptospirosis and cross-sectoral interventions for its prevention and control. In Prince Mahidol Award Conference 2013. Bangkok, Thailand: Prince Mahidol Award Conference; 2013.

5. Pappas G, Papadimitriou P, Siozopoulou V, Christou L, Akritidis N: The globalization of leptospirosis: worldwide incidence trends. Int J Infect Dis 2008, 12:351-357.

6. Monahan AM, Miller IS, Nally JE: Leptospirosis: risks during recreational activities. J Appl Microbiol 2009, 107:707-716.

7. Ricaldi JN, Vinetz JM: Leptospirosis in the tropics and in travelers. Curr Infect Dis Rep 2006, 8:51-58.

8. Sethi S, Sharma N, Kakkar N, Taneja J, Chatterjee SS, Banga SS, Sharma M: Increasing trends of leptospirosis in northern India: a clinico-epidemiological study. PLoS Negl Trop Dis 2010, 4:e579.

9. Picardeau M, Bertherat $E$, Jancloes M, Skouloudis AN, Durski K, Hartskeerl RA: Rapid tests for diagnosis of leptospirosis: current tools and emerging technologies. Diagn Microbiol Infect Dis 2014, 78:1-8.

10. Reis RB, Ribeiro GS, Felzemburgh RD, Santana FS, Mohr S, Melendez AX, Queiroz A, Santos AC, Ravines RR, Tassinari WS, Carvalho MS, Reis MG, Ko Al: Impact of environment and social gradient on leptospira infection in urban slums. PLoS Negl Trop Dis 2008, 2:e228.

11. Karande S, Gandhi D, Kulkarni M, Bharadwaj R, Pol S, Thakare J, De A: Concurrent outbreak of leptospirosis and dengue in Mumbai, India, 2002. J Trop Pediatr 2005, 51:174-181.

12. Kaur IR, Sachdeva R, Arora V, Talwar V: Preliminary survey of leptospirosis amongst febrile patients from urban slums of East Delhi. J AssoC Physicians India 2003, 51:249-251.

13. de Figueiredo CM, Mourao AC, de Oliveira MA, Alves WR, Ooteman MC, Chamone CB, Koury MC: Human leptospirosis in Belo Horizonte City, Minas Gerais, Brazil: a geographic approach. Rev Soc Bras Med Trop 2001, 34:331-338

14. Ganoza CA, Matthias MA, Collins-Richards D, Brouwer KC, Cunningham CB, Segura ER, Gilman RH, Gotuzzo E, Vinetz JM: Determining risk for severe leptospirosis by molecular analysis of environmental surface waters for pathogenic Leptospira. PLoS Med 2006, 3:e308.

15. Johnson MA, Smith H, Joeph P, Gilman RH, Bautista CT, Campos KJ, Cespedes M, Klatsky P, Vidal C, Terry H, Calderon MM, Coral C, Cabrera L, Parmar PS, Vinetz JM: Environmental exposure and leptospirosis, Peru. Emerg Infect Dis 2004, 10:1016-1022

16. Ivanova S, Herbreteau V, Blasdell K, Chaval Y, Buchy P, Guillard B, Morand S: Leptospira and rodents in Cambodia: environmental determinants of infection. Am J Trop Med Hyg 2012, 86:1032-1038.

17. Gamage CD, Amarasekera J, Palihawadana P, Samaraweera S, Mendis D, Janakan N, Lee RB, Obayashi Y, Tamashiro H: Analysis of hospital-based sentinel surveillance data on leptospirosis in Sri Lanka, 2005-2008. Jpn J Infect Dis 2012, 65:157-161

18. Padre LP, Watt $G$, Tuazon ML, Gray MR, Laughlin LW: A serologic survey of rice-field leptospirosis in Central Luzon, Philippines. Southeast Asian J Trop Med Public Health 1988, 19:197-199.

19. Everard CO, Hayes RJ, Fraser-Chanpong GM: A serosurvey for leptospirosis in Trinidad among urban and rural dwellers and persons occupationally at risk. Trans R Soc Trop Med Hyg 1985, 79:96-105.

20. Agampodi SB, Peacock SJ, Thevanesam V, Nugegoda DB, Smythe L, Thaipadungpanit J, Craig SB, Burns MA, Dohnt M, Boonsilp S, Senaratne T, Kumara A, Palihawadana P, Perera S, Vinetz JM: Leptospirosis outbreak in Sri Lanka in 2008: lessons for assessing the global burden of disease. Am J Trop Med Hyg 2011, 85:471-478.

21. Suarez Hernandez M, Martinez Sanchez R, Posada Fernandez PE, Vidal Garcia I, Bravo Fleites F, Sanchez Sibello A: Human leptospirosis outbreak in the district of Ciego de Avila, Cuba. Rev Soc Bras Med Trop 1999, 32:13-18.

22. Mollaret HH, Mailloux M, Debarbat F: Leptospirosis on the Island of Reunion. III. Epidemiologic study. Bull Soc Pathol Exot Filiales 1983, 76:744-749.

23. Ginebra Gonzalez O: Leptospirosis. Serological study of an epidemic outbrake in the province of Camaguey. Rev Cubana Med Trop 1976, 28:33-38.

24. Bourquin V, Ponte B, Hirschel B, Pugin J, Martin PY, Saudan P: Severe leptospirosis with multiple organ failure successfully treated by plasma 
exchange and high-volume hemofiltration. Case Rep Nephrol 2011, 2011:817414.

25. Herrero-Martinez JM, Fernandez-Ruiz M, Neil Hermenegildo Y, Gil H: [Leptospirosis in a sewer worker in Madrid: the role of molecular diagnosis]. Rev Clin Esp 2012, 212:554-555.

26. McLean M, Ruscoe Q, Kline T, King C, Nesdale A: A cluster of three cases of leptospirosis in dairy farm workers in New Zealand. N Z Med J 2014, 127:13-20.

27. Molineri A, Signorini ML, Perez L, Tarabla HD: Zoonoses in rural veterinarians in the central region of Argentina. Aust J Rural Health 2013, 21:285-290.

28. Bertherat E, Mueller MJ, Shako JC, Picardeau M: Discovery of a leptospirosis cluster amidst a pneumonic plague outbreak in a miners' camp in the Democratic Republic of the Congo. Int J Environ Res Public Health 2014, 11:1824-1833.

29. Poeppl W, Orola MJ, Herkner H, Muller M, Tobudic S, Faas A, Mooseder G, Allerberger F, Burgmann $\mathrm{H}$ : High prevalence of antibodies against Leptospira spp. in male Austrian adults: a cross-sectional survey, April to June 2009. Euro Surveill 2013, 18.

30. Lupi O, Netto MA, Avelar K, Romero C, Bruniera R, Brasil P: Cluster of leptospirosis cases among military personnel in Rio de Janeiro, Brazil. Int J Infect Dis 2013, 17:e129-131.

31. Burns DS, Bailey MS: Undifferentiated febrile illnesses in military personnel. J R Army Med Corps 2013, 159:200-205.

32. Hadad E, Pirogovsky A, Bartal C, Gilad J, Barnea A, Yitzhaki S, Grotto I, Balicer $\mathrm{RD}$, Schwartz E: An outbreak of leptospirosis among Israeli troops near the Jordan River. Am J Trop Med Hyg 2006, 74:127-131.

33. Leptospirosis outbreak in Eco Challenge 2000 participants. Commun Dis Rep CDR Wkly 2000, 10:341.

34. Wasinski B, Dutkiewicz J: Leptospirosis-current risk factors connected with human activity and the environment. Ann Agric Environ Med 2013, 20:239-244.

35. World Health Organization: Report of the second meeting of leptospirosis burden epidemiology reference group. In Book Report of the second meeting of leptospirosis burden epidemiology reference group. City: World Health Organization; 2011:1-34.

36. Goris MG, Boer KR, Duarte TA, Kliffen SJ, Hartskeerl RA: Human leptospirosis trends, the Netherlands, 1925-2008. Emerg Infect Dis 2013, 19:371-378.

37. van Crevel R, Speelman P, Gravekamp C, Terpstra WJ: Leptospirosis in travelers. Clin Infect Dis 1994, 19:132-134.

38. Leshem E, Segal G, Barnea A, Yitzhaki S, Ostfeld I, Pitlik S, Schwartz E: Travelrelated leptospirosis in Israel: a nationwide study. Am J Trop Med Hyg 2010, 82:459-463.

39. Hoffmeister B, Peyerl-Hoffmann G, Pischke S, Zollner-Schwetz I, Krause R, Muller MC, Graf A, Kluge S, Burchard GD, Kern WV, Suttorp N, Cramer JP: Differences in clinical manifestations of imported versus autochthonous leptospirosis in Austria and Germany. Am J Trop Med Hyg 2010, 83:326-335.

40. Jansen A, Schoneberg I, Frank C, Alpers K, Schneider T, Stark K: Leptospirosis in Germany, 1962-2003. Emerg Infect Dis 2005, 11:1048-1054.

41. Narita M, Fujitani S, Haake DA, Paterson DL: Leptospirosis after recreational exposure to water in the Yaeyama islands, Japan. Am J Trop Med Hyg 2005, 73:652-656.

42. Taniguchi $\mathrm{K}$, Yoshida M, Sunagawa T, Tada Y, Okabe N: Imported infectious diseases and surveillance in Japan. Travel Med Infect Dis 2008, 6:349-354.

43. Ariyapruchya B, Sungkanuparph S, Dumrongkitchaiporn S: Clinical presentation and medical complication in 59 cases of laboratoryconfirmed leptospirosis in Bangkok. Southeast Asian J Trop Med Public Health 2003, 34:159-164.

44. Katz AR, Ansdell VE, Effler PV, Middleton CR, Sasaki DM: Assessment of the clinical presentation and treatment of 353 cases of laboratory-confirmed leptospirosis in Hawaii, 1974-1998. Clin Infect Dis 2001, 33:1834-1841.

45. Jensenius M, Han PV, Schlagenhauf P, Schwartz E, Parola P, Castelli F, von Sonnenburg F, Loutan L, Leder K, Freedman DO: Acute and potentially life-threatening tropical diseases in western travelers-a GeoSentinel multicenter study, 1996-2011. Am J Trop Med Hyg 2013, 88:397-404.

46. Askling HH, Lesko B, Vene S, Berndtson A, Bjorkman P, Blackberg J, Bronner U, Follin P, Hellgren U, Palmerus M, Ekdahl K, Tegnell A, Struwe J: Serologic analysis of returned travelers with fever, Sweden. Emerg Infect Dis 2009, 15:1805-1808

47. Goldsmid JM, Bettiol SS, Sharples N: A preliminary study on travel health issues of medical students undertaking electives. J Travel Med 2003, 10:160-163.
48. Siikamaki HM, Kivela PS, Sipila PN, Kettunen A, Kainulainen MK, Ollgren JP, Kantele A: Fever in travelers returning from malaria-endemic areas: don't look for malaria only. J Travel Med 2011, 18:239-244.

49. Flores-Figueroa J, Okhuysen PC, von Sonnenburg F, DuPont HL, Libman MD, Keystone JS, Hale DC, Burchard G, Han PV, Wilder-Smith A, Freedman DO: Patterns of illness in travelers visiting Mexico and Central America: the GeoSentinel experience. Clin Infect Dis 2011, 53:523-531.

50. Field V, Gautret $P$, Schlagenhauf $P$, Burchard GD, Caumes E, Jensenius M Castelli F, Gkrania-Klotsas E, Weld L, Lopez-Velez R, de Vries P, von Sonnenburg F, Loutan L, Parola P, EuroTravNet network: Travel and migration associated infectious diseases morbidity in Europe, 2008. BMC Infect Dis 2010, 10:330.

51. Duplessis CA, Sklar MJ, Maves RC, Spichler A, Hale B, Johnson M, Bavaro M, Vinetz JM: Hemoptysis associated with leptospirosis acquired in Hawaii, USA. Emerg Infect Dis 2011, 17:2375-2377.

52. Coursin DB, Updike SJ, Maki DG: Massive rhabdomyolysis and multiple organ dysfunction syndrome caused by leptospirosis. Intensive Care Med 2000, 26:808-812.

53. Grobusch MP, Bollmann R, Schonberg A, Slevogt H, Garcia V, Teichmann D, Jelinek T, Flick H, Bergmann F, Rosseau S, Temmesfeld-Wollbrück B, Suttorp $\mathrm{N}$ : Leptospirosis in travelers returning from the Dominican Republic. J Travel Med 2003, 10:55-58.

54. Walter B, Wein B, Bittinger M, Messmann H: [Leptospirosis (Weil's disease) in Augsburg]. Dtsch Med Wochenschr 2010, 135:675-678.

55. Seilmaier M, Guggemos W: [Severe febrile illness with renal impairment after travel to Southeast Asia]. Internist (Berl) 2008, 49:1372, 1374-1376, 1378.

56. Steffens F, Landwehrs A, Goke MN: [Leptospirosis after a stay in Thailand]. Dtsch Med Wochenschr 2006, 131:1521-1524

57. Bernasconi E, Gayer R, Busolini E, Mombelli G: [Endemic and imported severe leptospirosis (Weil's disease) in southern Switzerland]. Schweiz Med Wochenschr 2000, 130:1487-1492.

58. Green AD, Busuttil W: Exotic disease in a traveller? A case of leptospirosis. Br J Gen Pract 1990, 40:123-124.

59. Teichmann D, Gobels K, Simon J, Grobusch MP, Suttorp N: A severe case of leptospirosis acquired during an iron man contest. Eur J Clin Microbiol Infect Dis 2001, 20:137-138.

60. Arcilla M, Wismans PJ, van Beek-Nieuwland Y, van Genderen PJ: Severe leptospirosis in a Dutch traveller returning from the Dominican Republic, October 2011. Euro Surveill 2012, 17.

61. Helmerhorst HJ, van Tol EN, Tuinman PR, de Vries PJ, Hartskeerl RA, Grobusch MP, Hovius JW: Severe pulmonary manifestation of leptospirosis. Neth J Med 2012, 70:215-221.

62. Kager PA, van Gorp EC, van Thiel PP: Fever and chills due to leptospirosis after travel to Thailand. Ned Tijdschr Geneeskd 2001, 145:184-186.

63. Wagenaar JF, de Vries PJ, Hartskeerl RA: Leptospirosis with pulmonary hemorrhage, caused by a new strain of serovar Lai: Langkawi. J Travel Med 2004, 11:379-381

64. Maldonado F, Portier H, Kisterman JP: Bilateral facial palsy in a case of leptospirosis. Scand J Infect Dis 2004, 36:386-388.

65. Arzouni JP, Parola P, La Scola B, Postic D, Brouqui P, Raoult D: Human infection caused by Leptospira fainei. Emerg Infect Dis 2002, 8:865-868.

66. Jaureguiberry S, Roussel M, Brinchault-Rabin G, Gacouin A, Le Meur A, Arvieux C, Michelet C, Tattevin P: Clinical presentation of leptospirosis: a retrospective study of 34 patients admitted to a single institution in metropolitan France. Clin Microbiol Infect 2005, 11:391-394.

67. Monsuez JJ, Kidouche R, Le Gueno B, Postic D: Leptospirosis presenting as haemorrhagic fever in visitor to Africa. Lancet 1997, 349:254-255.

68. Perret $J$, Velasque $L$, Morillon M, Martet G: [Leptospirosis: a cause of pseudo-malarial fever in Gabon]. Bull Soc Pathol Exot 1996, 89:217-219.

69. Simon F, Morand G, Roche C, Coton T, Kraemer P, Fournier PE, Gautret P. Leptospirosis in a French traveler returning from Mauritius. J Travel Med 2012, 19:69-71.

70. Heron LG, Reiss-Levy EA, Jacques TC, Dickeson DJ, Smythe LD, Sorrell TC: Leptospirosis presenting as a haemorrhagic fever in a traveller from Africa. Med J Aust 1997, 167:477-479.

71. Gill AC, Allen H, Campbell D: Fever in a teenage traveller. J Paediatr Child Health 2002, 38:610-611.

72. Korman TM, Globan MS, Smythe LD, Street AC: Leptospirosis in a returned traveller: isolation of a new Leptospira serovar. Aust N Z J Med 1997, 27:716-717.

73. Gelman SS, Gundlapalli AV, Hale D, Croft A, Hindiyeh M, Carroll KC: Spotting the spirochete: rapid diagnosis of leptospirosis in two returned travelers. J Travel Med 2002, 9:165-167. 
74. Mortimer RB: Leptospirosis in a caver returned from Sarawak, Malaysia. Wilderness Environ Med 2005, 16:129-131.

75. Pashkow FJ, Calisher CH, Reller LB, Sulzer CR: Leptospirosis in a traveler from Honduras. Colo Med 1981, 78:210-212

76. Haake DA, Dundoo M, Cader R, Kubak BM, Hartskeerl RA, Sejvar JJ, Ashford DA: Leptospirosis, water sports, and chemoprophylaxis. Clin Infect Dis 2002, 34:e40-43.

77. Paz A, Krimerman S, Potasman I: Leptospirosis masquerading as infectious enteritis. Travel Med Infect Dis 2004, 2:89-91.

78. Leung $\mathrm{V}$, Luong ML, Libman M: Leptospirosis: pulmonary hemorrhage in a returned traveller. CMAJ 2011, 183:E423-427.

79. Myrstad M, Tazmini K, Spaeren KH, Bucher A: A fit man with fever and pain in both thighs. Tidsskr Nor Laegeforen 2012, 132:668-670.

80. Lagi F, Corti G, Meli M, Pinto A, Bartoloni A: Leptospirosis acquired by tourists in Venice, Italy. J Travel Med 2013, 20:128-130.

81. Sakamoto M, Kato T, Sato F, Yoshikawa K, Yoshida M, Shiba K, Onodera S, Hoshina S, Koizumi N, Watanabe H: [A case of leptospirosis caused by Leptospira borgpetersenii serovar sejroe infected in Bali Island, Indonesia]. Kansenshogaku Zasshi 2005, 79:294-298.

82. Guron G, Holmdahl J, Dotevall L: Acute renal failure after a holiday in the tropics. Clin Nephrol 2006, 66:468-471.

83. Agampodi SB, Karunarathna D, Jayathilala N, Rathnayaka H, Agampodi TC, Karunanayaka $L$ : Outbreak of leptospirosis after white-water rafting: sign of a shift from rural to recreational leptospirosis in Sri Lanka? Epidemiol Infect 2014, 142:843-846.

84. Brett-Major DM, Lipnick RJ: Antibiotic prophylaxis for leptospirosis. Cochrane Database Syst Rev 2009, 3:CD007342.

doi:10.1186/s12992-014-0061-0

Cite this article as: Bandara et al:: Globalization of leptospirosis through travel and migration. Globalization and Health 2014 10:61.

\section{Submit your next manuscript to BioMed Central and take full advantage of:}

- Convenient online submission

- Thorough peer review

- No space constraints or color figure charges

- Immediate publication on acceptance

- Inclusion in PubMed, CAS, Scopus and Google Scholar

- Research which is freely available for redistribution

Submit your manuscript at www.biomedcentral.com/submit
() Biomed Central 